\title{
PERTIMBANGAN HAKIM PENGADILAN NEGERI MOJOKERTO TENTANG ANAK YANG MELAKUKAN PENGANIAYAAN MENURUT HUKUM ISLAM
}

\author{
\begin{tabular}{c|c} 
Abdurrohman & Lembaga Bantuan Hukum Surabaya \\
elzarazy@gmail.com & Jl. Kidal No 6 Pacar Keling Surabaya
\end{tabular}
}

\begin{abstract}
This article highlights the judge's consideration in Mojokerto Court against a child who does persecution then analyzed by Islamic law. The judge's decition in Mojokerto in sentencing for child who commits criminal act of persecution in the decision number: 20/Pid.B/2012/PN.Mkt in the form of returning to his parents is by the consideration that the offender is still minor, the crime committed is not a serious one, and the victim has forgiven (evidenced by a peace agreement dated 17 November 2011). Therefore, it is not contrary to the provision of Islamic Criminal Law. Because the judge's considerations could be the reason of forgiveness for the offender. Persecution conducted is not also included in the category of al-syajjâj (criminal by wounding in face and head), so that the sentence handed down is similar to that of ta'zîr.
\end{abstract}

Keywords: Judge's consideration, child, persecution, Islamic law.

\begin{abstract}
Abstrak: Artikel ini membahas tentang pertimbangan hakim Pengadilan Negeri Mojokerto terhadap anak yang melakukan penganiayaan kemudian dianalisis dengan hukum Islam. Keputusan hakim Pengadilan Negeri Mojokerto dalam penjatuhan hukuman bagi anak yang melakukan tindak pidana penganiayaan dalam putusan nomor: 20/Pid.B/2012/PN.Mkt berupa pengembalian kepada orang tuanya dengan pertimbangan bahwa pelaku masih tergolong anak di bawah umur, kejahatan yang dilakukan pelaku bukanlah kejahatan yang berat, serta korban sudah memaafkan (dibuktikan dengan surat perjanjian perdamian tertanggal I7 Nopember 2011), tidaklah bertentangan dengan ketentuan yang ada dalam hukum pidana Islam, karena pertimbangan-pertimbangan hakim tersebut bisa menjadi unsur pemaaf bagi pelaku tindak pidana. Penganiayaan yang dilakukan juga tidak termasuk dalam ketegori al-syajjâj (pidana pelukaan di bagian muka dan kepala), sehingga hukuman yang dijatuhkan sama halnya dengan ta'zîr.

Kata Kunci:Pertimbangan hakim, anak, penganiayaan, hukum Islam.
\end{abstract}




\section{Pendahuluan}

Anak merupakan amanah dan karunia Tuhan Yang Maha Esa yang memiliki harkat dan martabat sebagai manusia seutuhnya. Oleh karena itu, untuk menjaga harkat dan martabatnya, anak berhak mendapatkan perlindungan khusus, terutama perlindungan dalam sistem peradilan. ${ }^{1}$

Adapun hak-hak dasar anak adalah anak berhak memperoleh perlindungan, baik dari orang tua, masyarakat, dan negara, memperoleh pendidikan, terjamin kesehatan dan kesejahteraannya juga merupakan bagian dari hak-hak anak. Perlindungan tersebut dalam rangka menjamin pertumbuhan dan perkembangan fisik, mental, dan sosial secara utuh, serasi, dan seimbang. ${ }^{2}$ Jaminan perlindungan hak anak tersebut sesuai dengan nilai-nilai Pancasila dan tujuan negara sebagaimana tercantum dalam Pembukaan UUD $1945 .^{3}$

Pernyataan di atas tidak dapat dipungkiri mengingat masa anakanak marupakan saat-saat bagi seorang anak mengalami perubahan cepat dalam segala bidang, baik secara fisik maupun emosinya, serta belum stabil serta belum matang cara berfikirnya. Terutama pada masa remaja biasanya mudah cemas, mudah tergoncang emosinya dan sangat peka terhadap kritikan. Karena jiwanya yang belum stabil, terkadang mereka ingin terlepas dari segala peraturan yang dianggap mengekang kebebasan berekspresi, mudah menerima pengaruh dari luar lingkunganya dan ingin hidup dengan gayanya sendiri. Perilaku anak di bawah umur tidak cukup hanya dipandang sebagai kenakalan biasa, tidak jarang perbuatan mereka tidak sesuai dengan norma dan hukum yang berlaku atau dapat disebut sebagai penyelewengan terhadap norma yang telah disepakati yang menyebabkan terganggunya ketertiban dan ketentraman kehidupan manusia.

Penyelewengan yang demikian, biasanya oleh masyarakat dicap sebagai suatu pelanggaran dan bahkan sebagai suatu tindakan kriminal atau kejahatan yang dapat diancam pidana. Maka tidak heran jika banyak sekali kasus anak di bawah umur yang diajukan ke pengadilan karena kejahatan ringan seperti penggelapan, pencurian, dan penganiayaan. Tidak mengherankan pula jika akhirnya kebanyakan dari mereka

\footnotetext{
${ }^{1}$ UU. nomor 11 tahun 2012 tentang Sistem Peradilan Pidana Anak.

2 Darwan Prinst, Hukum Anak di Indonesia (Bandung: PT. Citra Aditya Bakti, 1997), 2.

${ }^{3}$ Irsan Koesparmono, Hukum Perlindungan Anak (Jakarta: UPN, 2006), 20.
} 
dijebloskan ke penjara. Justru yang memprihatinkan dan perlu diperhatikan adalah proses peradilan bagi anak di bawah umur yang seringkali disamaratakan dengan proses hukum bagi orang dewasa.

Hal ini jelas menjadi persoalan tersendiri, mengingat anak memiliki kekhususan dalam proses peradilan dan umur anak juga menjadi salah satu bahan pertimbangan bagi hakim dalam menjatuhkan hukumannya. Maka suatu pengklasifikasian terhadap umur akan sangat menentukan dapat atau tidaknya seseorang dijatuhi hukuman serta dapat tidaknya suatu tindak pidana dipertanggungjawabkan kepadanya dalam lapangan kepidanaan. Secara umum klasifikasi yang ingin ditonjolkan sebagai pendukung dari inti dalam persoalan ini sebenarnya adalah kedewasaan atau kalau dalam Islam dinamakan idrâk atau kemampuan berpikir seseorang, walaupun kedewasaan seseorang dengan orang yang lain tidak dapat disamakan. Namun dalam peristiwa hukum, klasifikasi ini akan selalu sama untuk suatu lapangan tertentu, karena menyangkut titik akhir yang ingin dicapai oleh para hakim dalam memutuskan suatu perkara dalam perasaan keadilan yang sebenarnya. ${ }^{4}$

Apabila mengacu pada Undang-undang nomor 11 tahun 2012 tentang Sistem Peradilan Pidana Anak, disebutkan dalam Pasal 1 ayat (1) bahwa keseluruhan proses penyelesaian perkara anak yang berhadapan dengan hukum, mulai tahap penyelidikan sampai dengan tahap pembimbingan setelah menjalani pidana harus diproses menggunakan undang-undang khusus pidana anak dan diselesaikan di Peradilan Anak. Begitu pula dalam pasal 1 ayat (3) juga sudah ditetapkan batas usia anak yang dapat dijatuhi hukuman. Dalam pasal tersebut diterangkan bahwa;

Anak yang berkonflik dengan hukum yang selanjutnya disebut anak adalah anak yang telah berumur 12 (dua belas) tahun, tetapi belum berumur 18 (delapan belas tahun) yang diduga melakukan tindak pidana. $^{5}$

Mengingat ciri dan sifat yang khas pada anak dan demi pelindungan terhadap anak, perkara anak yang berhadapan dengan hukum wajib disidangkan di pengadilan pidana anak yang berada di lingkungan peradilan umum. Proses peradilan perkara anak sejak

\footnotetext{
${ }^{4}$ E. Sumaryono, Kejahatan Anak: Suatu Tinjauan dari Psikologi dan Hukum (Yogyakarta: Liberty, 1985), 19.

${ }^{5}$ UU. nomor 11 tahun 2012 tentang Sistem Peradilan Anak.
} 
ditangkap, ditahan, dan diadili pembinaannya wajib dilakukan oleh pejabat khusus yang memahami masalah anak. Namun, sebelum masuk proses peradilan, para penegak hukum, keluarga, dan masyarakat wajib mengupayakan proses penyelesaian di luar jalur pengadilan, yakni melalui diversi berdasarkan pendekatan keadilan restoratif. ${ }^{6}$

Adapun mengenai tindak pidana anak dalam hukum pidana Islam, seorang anak tidak akan dikenakan hukuman had karena kejahatan yang dilakukannya, karena tidak ada beban tanggung jawab hukum terhadap seorang anak atas usia berapapun sampai dia mencapai usia dewasa (baligh), hakim hanya berhak untuk menegur kesalahannya atau menetapkan beberapa pembatasan baginya yang akan membantu memperbaikinya dan menghentikannya dari membuat kesalahan di masa yang akan datang. ${ }^{7}$

Hukum Islam telah menetapkan bahwa seorang anak tidak dapat dimintakan pertanggungjawaban sebelum ia dewasa. Hukum Islam mengampuni anak-anak dari hukuman yang semestinya dijatuhkan bagi orang dewasa kecuali jika ia telah baligh. Hal ini mengacu pada ayat:

"Dan apabila anak-anakmu telah sampai umur baligh, maka hendaklah mereka meminta izin, seperti orang-orang yang sebelum mereka meminta izin. Demikianlah Allah menjelaskan ayat-ayatNya, dan Allah swt Maha mengetahui lagi Maha Bijaksana." (QS. An-Nur: 59). ${ }^{8}$

Tafsîr al-Qur'ân al-Majîd an-Nûr memberikan penjelasan, bahwa dalam firman Allah swt tersebut terdapat peringatan bahwa seseorang dapat dibebani dengan hukum-hukum syariat adalah apabila orang tersebut telah sampai umur (baligh), dan sampai umur itu adalah ditandai dengan mimpi (laki-laki bermimpi bersetubuh dan mengeluarkan sperma) atau dengan usia (umur 15 tahun). Anak-anak yang telah sampai umur tidak boleh memasuki kamar orang tuanya tanpa izin terlebih dahulu, sama dengan orang lain. ${ }^{9}$

Rasulullah saw juga pernah bersabda dalam hadis sebagai berikut:

\footnotetext{
${ }^{6}$ Penjelasan UU. No.11 tahun 2012 Tentang Sistem Peradilan Pidana Anak.

${ }^{7}$ Abdurrahman I. Doi, Tindak Pidana dalam Syari'at Islam, diterjemahkan oleh Wadi Masturi \& Basri Iba Asghary, "Shari'ah the Islamic Lam"(Jakarta: Rineka Cipta, 1992), 16.

${ }^{8}$ Departemen Agama RI, Al-Qur'an dan Terjemahnya (Jakarta: 1983), 323.

9 Teungku Muhammad Hasbi ash-Shiddieqy, Tafsîr al-Qur'ân al-Majîd an-Nûr, Jilid 4 (Semarang: PT. Pustaka Rizki Putra, 2000), 2849.
} 
"Diangkat pena dari tiga hal: orang yang tidur hingga bangun, dari anak kecil sampai baligh, dan orang yang gila sampai berakal."10

Mayoritas fuqaha membatasi usia 15 (lima belas) tahun untuk lakilaki dan perempuan sebagai batas akhir dianggap baligh. Untuk itulah, jika di usia tersebut tanda-tanda baligh masih belum tampak juga, maka anak yang telah berusia 15 tahun, secara sendirinya ia telah dianggap baligh. Karena baligh inilah secara hukum seorang anak dianggap dan dibebani suatu kewajiban bagi dirinya sendiri. Ada sebagian kalangan yang berpendapat jika pertanggungjawaban pidana berkaitan dengan akal seseorang. Mereka beralasan karena yang mempengaruhi kedewasaan seseorang sebenarnya adalah akal. Akal adalah tanggung jawab hukum dan dengannya hukum berdiri. ${ }^{11}$

Ibnu Rusyd dalam kitabnya Bidâyah al-Mujtahid menjelaskan, bahwa yang menjadi syarat adanya pertanggung-jawaban bagi seorang pelaku kejahatan, entah itu melukai, membunuh atau mencuri adalah orang itu harus mukallaf. Sebab mukallaf adalah batasan usia dan kecerdasan seseorang dikenai beban untuk melaksanakan syari'at. Kecerdasan disini berkaitan dengan kedewasaan dan akal yang ada pada diri seseorang. ${ }^{12}$

Permasalahan tentang penetapan hukuman bagi anak menjadi hal yang menarik untuk dibahas, apalagi jika menilik terhadap Putusan Pengadilan Negeri Mojokerto Nomor: 20/Pid.B/2012/PN.Mkt yang mana dalam putusan tersebut hakim memberikan hukuman berupa "pengembalian kepada orang tua" terhadap terdakwa Philbert Titus Herdyanto Bin Pusoko Heru Santoso (umur 15 tahun) yang telah dinyatakan terbukti secara sah dan meyakinkan bersalah melakukan tindak pidana "melakukan penganiayaan" dengan memukul sebagian dari wajah Candrika Nornanda Nova Risco Santa yang mengakibatkan luka ringan dan lebam. Tindak pidana yang dilakukan terdakwa diatur secara khusus dan diancam pidana dengan pasal 80 ayat (1) Undang-undang nomor 23 tahun 2003 tentang Perlindungan Anak yang berbunyi:

\footnotetext{
${ }^{10}$ Abu Dawud, Sunan Abi Dawud Jilid III (Beirut: Dar al-Fikr, 1994), 289.

${ }^{11}$ Alie Yafie, et al., Ensiklopedia Hukum Pidana Islam, jilid 4 (Bogor: PT Kharisma IImu), 57.

${ }^{12}$ Ibnu Rusyd, Bidâyah al-Mujtahid, Analisa Fikih Para Mujtahid, penerjemah, Imam Ghazali Said \& Achmad Zaidun, terjemahan dari Bidâyah al-Mujtahid wa Nihâyah al-Muqtashid (Jakarta: Pustaka Amani, 2007), 530.
} 
"Setiap orang yang melakukan kekejaman, kekerasan atau ancaman kekerasan, atau penganiayaan terhadap anak, dipidana dengan pidana penjara paling lama 3 (tiga) tahun 6 (enam) bulan dan/atau denda paling banyak Rp 72.000.000,00 (tujuh puluh dua juta rupiah)"

Secara umum, tindak pidana penganiayaan juga diatur dalam Kitab Undang-undang Hukum Pidana pasal 351 yang berbunyi:

(1) Penganiayaan diancam dengan pidana penjara paling lama dua tahun delapan bulan atau pidana denda paling banyak empat ribu lima ratus rupiah.

(2) Jika perbuatan mengakibatkan luka-luka berat, yang bersalah diancam dengan pidana penjara paling lama lima tahun.

Dalam asas-asas hukum pidana dijelaskan, bahwa seseorang tidak akan dituntut secara pidana akibat perbuatannya apabila belum ada aturan yang menyatakan bahwa perbuatan tersebut merupakan perbuatan pidana atau dapat dikenai hukuman. Dengan kata lain, seseorang akan dituntut secara pidana, apabila melanggar aturan yang telah ada, baik melakukan suatu perbuatan yang dilarang atau meninggalkan perbuatan yang diperintahkan. Penjelasan ini ternuat dalam pengertian asas legalitas hukum pidana Islam. ${ }^{13}$

Sementara dalam hukum pidana Islam, tindak pidana penganiayaan, dikatagorikan sebagai jarîmah qishâsh, ${ }^{14}$ yang mana si pelaku tindak kejahatan ini diancam dengan hukuman yang setimpal dengan apa yang telah dilakukan. Secara eksplisit hal ini dijelaskan dalam al-Qur'an Surah al-Maidah ayat 45, sebagai berikut:

Dan Kami telah tetapkan terhadap mereka di dalamnya (At Taurat) bahwasanya jiwa (dibalas) dengan jiwa, mata dengan mata, hidung dengan hidung, telinga dengan telinga, gigi dengan gigi, dan luka luka (pun) ada qishâshnya. Barangsiapa yang melepaskan (hak qishâsh)nya, maka melepaskan hak itu (menjadi) penebus dosa baginya. Barangsiapa tidak memutuskan perkara menurut apa yang diturunkan Allah, maka mereka itu adalah orang-orang yang zalim. ${ }^{15}$

\footnotetext{
${ }^{13}$ Jaih Mubarok, Enceng Arif Faizal, Asas-Asas Hukum Pidana Islam (Jakarta: Anggota Ikapi, 2004), 40.

${ }^{14}$ Nurul Irfan, Masyrofah, Fiqh Jinayah (Jakarta: Amzah, 2013), 8.

${ }^{15}$ M. Quraish Shihab, al-Qur'an dan Maknanya (Tangerang: Lentera Hati, 2010), 115.
} 
Maka dari itu, dalam artikel ini dibahas tentang pertimbangan hakim Pengadilan Negeri Mojokerto dalam kasus penganiayaan yang dilakukan oleh anak menurut hukum Islam.

\section{Delik Penganiayaan dan Sanksinya menurut Hukum Pidana Islam}

Dalam Ensiklopedi Hukum Islam, jarîmah penganiayaan ini diterangkan dengan istilah tindak pidana terhadap selain nyawa, maksudnya adalah tindak pidana terhadap anggota tubuh manusia, baik berbentuk pemukulan atau pelukaan. ${ }^{16}$

Menurut Wahbah Zuhaili, tindak pidana atas selain jiwa adalah setiap tindakan melawan hukum atas badan manusia, baik berupa pemotongan anggota badan, pelukaan, maupun pemukulan, sedangkan jiwa atau nyawa dan hidupnya masih tetap tidak terganggu. ${ }^{17}$

Inti dari unsur tindak pidana atas selain jiwa ini adalah perbuatan menyakiti. Dengan demikian, yang termasuk dalam pengertian perbuatan menyakiti adalah setiap jenis pelanggaran yang bersifat menyakiti atau merusak anggota badan manusia, seperti perlukaan, pemukulan, pencekikan, pemotongan, dan penempelengan.

Ada dua klasifikasi dalam menentukan pembagian tindak pidana penganiayaan atau tindak pidana atas selain jiwa ini, yaitu; ditinjau dari segi niat pelakunya dan ditinjau dari segi objek (sasarannya).

a. Ditinjau dari segi niatnya

Apabila ditinjau dari segi niat pelaku, tindak pidana atas selain jiwa dapat dibagi kepada dua bagian yaitu; tindak pidana dengan disengaja dan tindak pidana dengan tidak disengaja.

b. Ditinjau dari objek/sasarannya

Apabila ditinjau dari segi objek atau sasarannya, tindak pidana atas selain jiwa, baik disengaja atau tidak disengaja dapat dibagi dalam lima bagian;

(1) Penganiaan atas anggota badan dan semacamnya. Yaitu tindakan perusakan terhadap anggota badan dan anggota lain yang disertakan dengan anggota badan, baik berupa pemotongan maupun pelukaan.

\footnotetext{
${ }^{16}$ A. Rahman Ritonga et al, Ensiklopedi Hukum Islam (Jakarta: PT. Ichtiar Baru van Hoeve, 2006), 1387.

${ }^{17}$ Wahbah Zuhaili, Al-figh Al-lslâmiy wa Adillatuhu (Damaskus: Dar Al-Fikr, 1989), 331.
} 
(2) Menghilangkan manfaat anggota badan, sedangkan jenisnya masih tetap utuh.

(3) Al-syajjâj yaitu pelukaan khusus pada bagian muka dan kepala.

(4) Al-jirâh yaitu pelukaan pada anggota badan selain wajah, kepala, dan ini. Anggota badan yang pelukaannya termasuk jirâh ini meliputi leher, dada, perut, sampai batas pinggul.

(5) Tindakan selain yang telah disebutkan di atas. Adapun yang termasuk dalam kelompok ini adalah setiap tindakan pelanggaran, atau menyakiti yang tidak sampai merusak athrâf atau menghilangkan manfaatnya, dan tidak pula menimbulkan luka syajjâj $j$ atau jirâh. Seperti contoh pemukulan pada bagian muka, tangan, kaki, atau badan, tapi tidak sampai menimbulkan atau mengakibatkan luka, melainkan hanya memar, muka merah, atau terasa sakit. ${ }^{18}$

\section{Hukuman bagi Pelaku Tindak Pidana Penganiayaan}

Sebagaimana telah dikemukakan di atas bahwa apabila ditinjau dari segi objek atau sasarannya, tindak pidana penganiayaan itu dibagi dalam lima bagian, yaitu perusakan anggota badan dan sejenisnya, menghilangkan manfaatnya, syajjâj, jirâh, dan tindakan yang tidak termasuk dalam keempat jenis tersebut. Hukuman untuk tindak pidana penganiayaan tergantung pada akibat yang ditimbulkan atas kelima jenis tindak pidana tersebut, baik perbuatannya dilakukan dengan disengaja atau tidak. Hukuman pokok (asli) terhadap tindak pidana perlukaan atau pemukulan yang dilakukan dengan sengaja adalah qishâsh, jika mungkin dilaksanakan. Sedangkan untuk yang menyerupai sengaja dan kekeliruan, hukuman pokoknya adalah diyat. ${ }^{19}$

Mayoritas Ulama fikih menyatakan kesepakatannya akan hukuman qishâsh sebagai hukuman asli untuk terpidana dalam kasus penganiayaan ini sesuai dengan firman Allah swt dalam Surah al-Maidah (5) ayat 45 sebagai berikut:

Dan Kami telah tetapkan terhadap mereka di dalamnya (At Taurat) bahwasanya jiwa (dibalas) dengan jiwa, mata dengan mata, hidung dengan hidung, telinga dengan telinga, gigi dengan gigi, dan luka

\footnotetext{
${ }^{18}$ Ahmad Wardi Muslich, Hukum Pidana Islam (Jakarta: Sinar Grafika, 2005), 183.

19 Ibid, 184.
} 
luka (pun) ada kisasnya. Barangsiapa yang melepaskan (hak kisas) nya, maka melepaskan hak itu (menjadi) penebus dosa baginya. Barangsiapa tidak memutuskan perkara menurut apa yang diturunkan Allah, Mmka mereka itu adalah orang-orang yang zalim..$^{20}$

Dari dalil hukum yang tercantum pada ayat al-Qur'an tersebut dapat difahami bahwa apabila seseorang melakukan tindak kejahatan terhadap orang lain, misalnya menusukkan parang ke bagian perut, maka pelakunya dikenakan sanksi hukum, yaitu perutnya ditusuk dengan parang juga agar ia menderita sebagaimana orang lain yang menderita karena perbuatannya. Kecuali jika korban memaafkan kejahatannya tersebut. ${ }^{21}$ Adapun hukuman pengganti dalam kasus penganiayaan ini, menurut ijma' (kesepakatan) ahli fikih adalah diyat, baik tindak pidana ini dilakukan dengan sengaja ataupun tersalah. ${ }^{22}$

Namun apabila tindak pidana atas selain jiwa ini tidak menimbulkan perusakan anggota badan, menghilangkan manfaatnya, juga tidak menimbulkan syajjâj dan jirâh, maka dalam kasus ini tidak berlaku hukuman qishâsh. Tindakan penempelengan, pemukulan dengan cambuk dan tongkat semuanya tidak dikenakan hukuman qishâsh apabila tidak meninggalkan bekas. Hukumannya adalah ganti rugi yang tidak tertentu atau hukûmah, yaitu ganti rugi yang ketentuannya diserahkan kepada kebijaksanaan dan ijtihad hakim dan ini hampir mirip dengan ta'zîr. ${ }^{23}$

\section{Konsep Hukum Islam Mengenai Batas Usia Anak yang Dapat Dikenai Sanksi Hukum}

Al-walad atau anak adalah keturunan yang kedua orang yang lahir dari rahim seorang ibu, baik laki-laki maupun perempuan atau khunsa, sebagai hasil dari persetubuhan antara dua lawan jenis. Dalam hukum Islam dibedakan antara anak yang masih kecil (belum baligh) dan anak yang sudah baligh. Anak yang masih kecil ada yang belum mumayyiz

\footnotetext{
${ }^{20}$ Kementrian Agama, al-Qur'an dan Tafsirnya, Jilid 2, 115.

${ }^{21}$ Zainuddin Ali, Hukum Islam Pengantar IImu Hukum di Indonesia (Jakarta: Sinar Grafika, 2006), 128.

${ }^{22}$ A. Rahman Ritonga et al, Ensiklopedi Hukum Islam, 1387.

${ }^{23}$ Ahmad Wardi Muslich, Hukum Pidana Islam, 218.
} 
(belum bisa membedakan yang hak dan batil) dan ada yang sudah mumayyiz. ${ }^{24}$

Maksud kriteria di bawah umur ialah anak yang belum baligh (belum mukallaf), baik karena akalnnya belum matang atau karena yang lainnya. Ia harus diawasi dan dijaga oleh walinya.

Ciri-ciri seorang baligh adalah sebagai berikut:

1. Secara yuridis telah berusia 15 tahun bagi laki-laki atau haidbagi perempuan. ${ }^{25}$ Dalam sebuah Hadis yang diriwayatkan oleh Imam Abu Dawud dari Ibnu Umar r.a. yaitu:

"Sesungguhnya Nabi Saw. membawa (Ibnu Umar) pada perang Uhud, sedang ia adalah bocah berumur 14 tahun, maka ia tidak dibolehkan berperang. Dan Nabi membawanya pada hari perang khandaq dan ia adalah bocah berumur 15 tahun, maka ia dibolehkannya." ${ }^{26}$

2. Secara psikologis telah tumbuh rambut di kemaluan, dinyatakan dalam salah satu Hadis yang diriwayatkan oleh Imam Abu Dawud dan dari 'Athiyyah al-Quraidzah r.a. berkata:

"Saya termasuk dari pemuda Bani Quraidzah, maka mereka melihat keberadaan saya. Barang siapa yang telah tumbuh bulu (di kemaluannya) maka ia akan dibunuh. Dan barang siapa yang masih belum tumbuh bulu (di kemaluannya) maka tidak dibunuh. Maka aku termasuk orang yang belum tumbuh bulu. ${ }^{27}$

3. Telah bermimpi, yang dimaksud adalah mimpi bersetubuh, baik laki-laki maupun perempuan, disamakan dengan mimpi orang yang sudah keluar mani, baik di waktu sadar maupun sedang tidur atau sudah memiliki syahwat untuk bersetubuh, dalam sebuah Hadis yang diriwayatkan Abu Dawud r.a., Ali berkata:

"Pernah aku menghafal hadis dari Nabi Muhammad saw yang mengatakan: tidak dianggap anak yatim sesudah bermimpi." ${ }^{28}$

Menurut Hukum Islam yang disebut anak adalah jika belum mencapai umur baligh, dimana batas umur baligh apabila kalau laki-

\footnotetext{
${ }^{24}$ A. Rahman Ritonga et al, Ensiklopedi Hukum Islam, 112.

${ }^{25}$ Hendi Suhendi, Fiqh Muamalah (Jakarat: Raja Grafindo Persada, 2008), 224.

${ }^{26}$ Abu Dawud, Sunan Abi Dawud, Jilid IV (Mesir: Darul Hadst, 1999), 1884.

${ }^{27} \mathrm{Ibid}, 1883$.

${ }^{28}$ Abu Dawud, Sunan Abi dawud, Jilid II (Beirut: Dar Al-IImiyah, 1996), 323.
} 
laki sudah bermimpi dan mengeluarkan air mani dan anak perempuan apabila sudah datang haid. Salah satu fakta hukum mengenai usia dewasa anak adalah ketika Nabi Muhammad Saw. Menikahi 'Aisyah binti Abu Bakar di mana 'Aisyah dinikahi Nabi tidak lama setelah Nabi Muhammad saw menikahi Saudah. Ketika itu 'Aisyah masih berusia enam tahun atau tujuh tahun ${ }^{29}$ dan Nabi Muhammad saw menggaulinya setelah berumur sembilan tahun. ${ }^{30}$

Pendapat para ahli fikih mengenai kedudukan anak berbedabeda menurut masa yang dilaluinya, yaitu:

1. Masa tidak adanya kemampuan berpikir. Masa ini dimulai sejak lahir sampai usia 7 tahun, perbuatan pidana yang dilakukannya tidak dikenai hukuman.

2. Masa kemampuan berpikir lemah. Masa ini dimulai sejak anak berusia 7 tahun sampai usia 15 tahun. Pada masa tersebut mereka dijatuhi pengajaran. Pengajaran ini meskipun sebenarnya hukuman namun tetap dianggap sebagai hukuman mendidik bukan hukuman pidana.

3. Masa kemampuan berpikir penuh. Masa ini dimulai sejak anak mencapai usia kecerdasan yang pada umumnya telah mencapai usia 15 tahun atau 18 tahun. Pada masa ini telah dikenakan pertanggungjawaban pidana atas tindak pidana yang dilakukan. ${ }^{31}$ Adapun menurut Sayyid Sabiq, yang dimaksud dengan batas anak adalah apabila ia telah bermimpi dengan kata lain sudah baligh. Salah satu tanda baligh itu adalah telah sampai umur 15 tahun. ${ }^{32}$

Menurut Abdul Qadir Audah anak di bawah umur dapat ditentukan bahwa laki-laki itu belum keluar sperma dan bagi perempuan belum haid, ihtilâm dan belum pernah hamil. Menurut Jumhur Fuqaha berpendapat bahwa kedudukan anak laki-laki dan anak perempuan sama yakni tentang kedewasaannya yaitu keluarnya sperma dan telah haid serta terlihatnya kecerdasan. ${ }^{33}$

\footnotetext{
${ }^{29}$ Waryono Abdul Ghafur, Tafsir Sosial Mendialogkan Teks dengan Konteks (Yogyakarta: elSAQ Press, 2005), 82.

30 Amir Syarifuddin, Hukum Perkawinan Islam di Indonesia antara Fiqh Munakahat dan UU. Perkawinan (Jakarta: Kencana Prenada media, 2009), 66.

${ }^{31}$ Sudarsono, Kenakalan Remaja (Jakarta : Rineka Cipta, 1991), hlm. 10

${ }^{32}$ Sayyid Sabiq, Fiqh Sunnah, Jilid III (Semarang: Toha Putra, ), 410.

${ }^{33}$ Ibnu Rusyd, Bidâyah al-Mujtahid, Jilid II (ttp.: Wahriyai al-Kitab al-Arabiyah, tt.), 211.
} 


\section{Ketentuan Hukuman bagi Anak yang Melakukan Tindak Pidana Menurut Hukum Pidana Islam}

Seorang anak tidak dikenakan hukuman had karena kejahatan yang dilakukannya, karena tidak ada tanggung jawab hukum atas seorang anak yang berusia berapapun sampai dia mencapai umur puber. Qadhi hanya akan tetap berhak untuk menegur kesalahannya untuk menetapkan beberapa batasan baginya yang akan membantu memperbaikinya dan menghentikannya dari membuat kesalahan lagi di masa yang akan datang. Menurut Abu Zaid al-Qayrawani, seorang Ulama Madzhab Maliki, tetap tidak ada hukuman had bagi anak-anak kecil bahkan juga dalam hal tuduhan zina yang palsu (qadzaf) atau justru si anak sendiri yang melakukannya. ${ }^{34}$

Sanksi pidana dalam fikih jinâyah bisa dihapus karena ada sebab yang berkaitan dengan perbuatan si pelaku dan karena ada sebab yang berkaitan dengan kondisi si pelaku itu sendiri. Hal yang pertama, perbuatannya menjadi boleh dilakukan yang biasanya disebut dengan unsur pembenar. Kedua, perbuatan si pelaku tetap haram akan tetapi kepadanya tidak bisa dijatuhi hukuman mengingat kondisi si pelaku itu sendiri yang biasanya disebut dengan unsur pemaaf. ${ }^{35}$

Dalam Eksiklopedi Fiqih Umar bin Khattab, Muhammad Rawwas Qal'ahji menerangkan, bahwa jika ada seorang manusia melakukan tindak kriminal dengan sengaja, baik kriminal ini berupa pembunuhan atau yang lainnya dan hukumanya adalah qishâsh, maka sesungguhnya qishâsh itu tidak akan dilaksanakan kecuali kepada mereka yang sudah baligh (dewasa), berakal, bukan karena terpaksa dan orang yang terjaga darahnya. Riwayat tentang syarat baligh adalah bahwa Umar bin Khattab pernah berkata: "Tidak ada qishâsh karena pembunuhan, tidak ada qishâsh karena melukai, tidak ada hukuman dan siksaan kepada orang yang belum baligh, belum pernah bermimpi, sampai dia bisa membedakan mana yang baik dan mana yang buruk. ${ }^{36}$

\footnotetext{
${ }^{34}$ Abdurrahman I Doi, Tindak Pidana dalam Syari'at Islam (Jakarta: Rineka Cipta, 1992), 16.

${ }^{35}$ A. Djazuli, Hukum Pidana Islam, 243.

${ }^{36}$ Muhammad Rawwas Qal'ahji, Ensiklopedi Fiqh Umar bin Khattab (Jakarta: PT Raja Grafindo Persada, 1999), 278.
} 
Ali bin Abi Thalib juga pernah berkata kepada Umar bin Khattab: Apakah engkau tahu bahwa tidaklah dicatat perbuatan baik atau buruk, dan tidak pula dituntut tanggung jawab atas apa yang dilakukan, karena hal berikut:

1. Orang yang gila sampai dia sadar;

2. Anak-anak sampai dia mencapai usia puber, ${ }^{37}$ dan

3. Orang yang tidur sampai ia bangun. (Riwayat Imam Bukhari) ${ }^{38}$

Oleh sebab itu, jika anak di bawah umur (belum menginjak usia baligh) melakukan tindak kejahatan dan semacamnya maka tidak seyogyanya ditindak dengan hukuman pidana layaknya orang dewasa (penjara kurungan) karena mental mereka masih lemah, mengenai hal ini sebaiknya dilakukan dengan cara lain yang lebih mendidik dan bisa menyadarkan mereka. ${ }^{39}$

\section{Ketentuan Hukuman bagi Anak yang Melakukan Tindak Pidana Menurut Undang-undang Nomor 11 Tahun 2012 tentang Sistem Peradilan Pidana Anak}

Penjatuhan hukuman terhadap anak adalah upaya hukum yang bersifat ultimum remedium artinya penjatuhan pidana terhadap anak merupakan upaya hukum yang terakhir setelah tidak ada lagi upaya hukum lain yang menguntungkan bagi anak, misalnya anak itu memang sudah meresahkan keluarga dan masyarakat, berkali-kali telah melakukan tindak pidana dan pihak orang tua atau wali sudah tidak ada lagi yang sanggup untuk mendidik dan mengawasinya. ${ }^{40}$

Jika hakim terpaksa harus menjatuhkan tindak pidana yang telah melakukan tindak pidana, hakim dapat menerapkan pasal 47 ayat $(1,2$, dan 3) KUHP yaitu:

1. Mengurangi sepertiga dari pidana pokok

2. Menjatuhkan pidana penjara selama-lamanya 15 tahun bagi yang diancam pidana mati atau seumur hidup

\footnotetext{
${ }^{37}$ Syarat-syarat orang wajib diqishâsh diantaranya, pembunuh adalah orang yang sudah dewasa. Maka tidak ada qishâsh terhadap anak kecil. Seandainya pembunuh berkata: "pada saat ini saya masih anak-anak", maka pengakuan itu dapat dibenarkan tanpa sumpah. Lihat: al-Imam asy-Syekh Muhammad bin Qasim al-Ghazi, Fath al-Qarîb, jilid II, Penterjemah: A. Hidayah, 124.

${ }^{38}$ Abdur Rahman I, Tindak Pidana dalam Syari'at Islam, Penterjemah: Wadi Masturi, Basri Iba Asghary (Jakarta: Rineka Cipta, 1992), 15.

${ }^{39}$ Quraisy Syihab, Mempersiapkan Anak Sholeh (Jakarta: Raja Grafindo Persada, 1996), 4.

${ }^{40}$ Bunadi Hidayat, Pemidanaan Anak di Bawah Umur, 84.
} 
3. Meniadakan pidana tambahan, penjabutan beberapa hak tertentu dan pengumuman keputusan hakim. ${ }^{41}$

Ringannya perbuatan, keadaan pribadi anak, atau keadaan pada waktu dilakukan perbuatan atau yang terjadi kemudian dapat dijadikan dasar pertimbangan hakim untuk tidak menjatuhkan pidana atau mengenakan tindakan dengan mempertimbangkan segi keadilan dan kemanusiaan. Selain itu, sanksi terhadap anak di bawah umur juga bisa ditentukan berdasarkan perbedaan umur anak itu sendiri, yaitu:

1. Bagi anak yang masih berumur kurang dari 14 (empat belas) tahun hanya dapat dikenai tindakan,

2. Bagi anak yang telah mencapai umur 14 (empat belas) tahun sampai dengan 18 (delapan belas) tahun dapat dijatuhi tindakan dan pidana. ${ }^{42}$

Adapun yang dimaksud dengan sanksi tindakan bagi anak yang berumur kurang dari 14 (empat belas) tahun dalam bahasan di atas adalah tindakan-tindakan yang dikenakan terhadap anak yang melakukan tindak kriminal berupa:

1. Pengembalian kepada orang tua/wali;

2. Penyerahan kepada seseorang;

3. Perawatan di rumah sakit jiwa;

4. Perawatan di LPKS;

5. Kewajiban mengikuti pendidikan formal dan/atau pelatihan yang diadakan oleh pemerintah atau badan swasta;

6. Pencabutan surat izin mengemudi; dan/atau

7. Perbaikan akibat tindak pidana. ${ }^{43}$

Sedangkan sanksi pidana bagi anak yang telah berumur lebih dari 14 (empat belas) tahun dalam pasal 71 Undang-undang nomor 11 tahun 2014 tentang Sistem Peradilan Pidana Anak dijelaskan bahwa sanksi pidana untuk anak di bawah umur itu dibagi menjadi dua, yaitu sanksi pidana pokok dan sanksi pidana tambahan. Pidana pokok bagi anak terdiri atas:

1. Pidana peringatan. Yaitu pidana ringan yang tidak mengakibatkan pembatasan kebebasan anak.

\footnotetext{
${ }^{41}$ Pasal 47 Kitab Undang-Undang Hukum Pidana.

${ }^{42}$ Pasal 69 UU. No.11 tahun 2014 tentang Sistem Peradilan Pidana Anak.

${ }^{43}$ Pasal 82 UU. No. 11 tahun 2012 tentang Sistem Peradilan Pidana Anak.
} 
2. Pidana dengan syarat:

a) Pembinaan di luar lembaga. Pidana pembinaan di luar lembaga dapat berupa keharusan: (1) Mengikuti program pembimbingan dan penyuluhan yang dilakukan oleh pejabat pembina; (2) Mengikuti terapi di rumah sakit jiwa; atau (3) Mengikuti terapi akibat penyalahgunaan alkohol, narkotika, psikotropika, dan zat adiktif lainnya.

b) Pelayanan masyarakat; merupakan pidana yang dimaksudkan untuk mendidik anak dengan meningkatkan kepeduliannya pada kegiatan kemasyarakatan yang positif.

c) Pengawasan. Yaitu anak ditempatkan di bawah pengawasan Penuntut Umum dan dibimbing oleh Pembimbing Kemasyarakatan.

3. Pelatihan kerja yang dilaksanakan di lembaga yang melaksanakan pelatihan kerja yang sesuai dengan usia anak. Pelatihan kerja ini dikenakan paling singkat 3 (tiga) bulan dan paling lama 1 (satu) tahun.

4. Pembinaan dalam lembaga; Pidana pembinaan di dalam lembaga dilakukan di tempat pelatihan kerja atau lembaga pembinaan yang diselenggarakan, baik oleh pemerintah maupun swasta. Pidana pembinaan di dalam lembaga dijatuhkan apabila keadaan dan perbuatan anak tidak membahayakan masyarakat. Pembinaan dalam lembaga dilaksanakan paling singkat 3 (tiga) bulan dan paling lama 24 (dua puluh empat) bulan.

5. Penjara: Anak dijatuhi pidana penjara di LPKA apabila keadaan dan perbuatan anak akan membahayakan masyarakat. Pidana penjara yang dapat dijatuhkan kepada anak paling lama 1/2 (satu perdua) dari maksimum ancaman pidana penjara bagi orang dewasa. Pembinaan di LPKA ini dilaksanakan sampai anak berumur 18 (delapan belas) tahun. Anak yang telah menjalani 1/2 (satu perdua) dari lamanya pembinaan di LPKA dan berkelakuan baik berhak mendapatkan pembebasan bersyarat. Pidana penjara terhadap anak hanya digunakan sebagai upaya terakhir. Jika tindak pidana yang dilakukan anak merupakan tindak pidana yang diancam dengan 
pidana mati atau pidana penjara seumur hidup, pidana yang dijatuhkan adalah pidana penjara paling lama 10 (sepuluh) tahun. ${ }^{44}$ Sedangkan pidana tambahan terdiri atas:

1. Perampasan keuntungan yang diperoleh dari tindak pidana; atau

2. Pemenuhan kewajiban adat. ${ }^{45}$

\section{Deskripsi Kasus dalam Putusan Nomor: 20/Pid.B/2012/Pn.Mkt}

Terdakwa Philbert Titus Herdyanto bin Pusoko Heru Santoso (Usia 15 tahun/tanggal lahir 24 April 1996) pada hari Rabu tanggal 5 Oktober 2011 sekira jam 17.00 Wib atau setidak-tidaknya pada suatu waktu dalam bulan Oktober tahun 2011, bertempat di Jalan belakang GOR Desa Sooko Kecamatan Sooko Kabupaten Mojokerto atau setidaktidaknya pada suatu tempat yang masih termasuk dalam daerah hukum Pengadilan Negeri Kelas I A Mojokerto telah melakukan kekejaman, kekerasan atau ancaman kekerasan atau penganiayaan terhadap anak (saksi/korban) Candrika Nornanda Nova Risco Santa, perbuatan dilakukan dengan cara sebagai berikut:

Pada awalnya, terdakwa Philbert Titus Herdyanto Bin Pusoko Heru Santoso menjemput saksi/korban Candrika Nornanda Nova Risco Santa pulang sekolah dan ditunggu lama saksi tidak datang-datang, dan setelah datang, tersangka langsung membonceng saksi sambil marahmarah, tetapi saksi tidak respon yang saat itu sedang main hand phone (HP) sehingga membuat tersangka marah dan selanjutnya tersangka mengambil HP milik saksi dan langsung memukulnya dengan menggunakan tangan kiri ke arah belakang dan mengenai mata saksi/korban sebelah kanan hingga mengakibatkan lebam pada kelopak mata kanan dan merah seperti darah beku di sekitar retina mata saksi sebelah kanan, sebagaimana dalam Visum Et Repertum No.353/300/416103.1/2011 tanggal 6 Oktober 2011 yang dibuat dan ditanda tangani oleh dokter Gerita Indira Agusni sebagai dokter jaga di RSP/Puskesmas pada Dinas Kesehatan Kabupaten Mojokerto, dengan hasil pemeriksaan sebagai berikut: Bagian Kepala terdapat luka lecet dengan panjang kurang lebih setengah $\mathrm{cm}$ pada ujung pangkal alis kanan. Serta terdapat pendarahan di

\footnotetext{
${ }^{44}$ Pasal 71 sampai Pasal 81 UU. No. 11 tahun 2012 tentang Sistem Peradilan Pidana Anak.

${ }^{45}$ Pasal 71 ayat (2) UU. No. 11 tahun 2012 tentang Sistem Peradilan Pidana Anak.
} 
bawah kulit dengan ukuran lebih dua kali satu setengah $\mathrm{cm}$ pada bawah mata sebelah kanan, juga terdapat pendarahan pada bola mata kanan. ${ }^{46}$

Kesimpulannya; penyebab terjadiya luka tersebut di atas adalah disebabkan persentuhan dengan benda tumpul. Dan menurut hasil diagnosa: kerusakan tersebut di atas disebabkan oleh persentuhan dengan benda tumpul yang tidak mengakibatkan penyakit atau halangan dalam menjalankan pekerjaan, jabatan atau mata pencaharian. Penderita tersebut belum sembuh sama sekali akan tetapi tidak perlu rawat inap di rumah sakit. Besarnya kemungkinan ia akan sembuh jika sekiranya tidak ada halhal yang menambah penyakitnya (komplikasi). ${ }^{47}$

Perbuatan terdakwa sebagaimana disebutkan di atas, diatur dan diancam pidana dengan pasal 80 ayat (1) UU. No. 23 tahun 2001 tentang Perlindungan Anak dan diancam juga dengan pasal 351 ayat (1) Kitab Undang-Undang Hukum Pidana (KUHP). Dan dalam persidangan, terdakwa menyatakan akan maju sendiri tanpa didampingi penasehat hukumnya Mochamad Osin, SH, Haryono, SH, dan Achmad Lutfi, SH. ${ }^{48}$

Pada saat proses penuntutan, Jaksa Penuntut Umum mengajukan alat bukti berupa 1 (satu) buah HP merk Nokia Tipe 2626 dan juga membacakan hasil Visum Et Repertum tertanggal 06 Oktober 2011 yang dibuat dan di tanda tangani oleh dokter Gerita Indira Agusni sebagai dokter jaga di RSP/Puskesmas pada Dinas Kesehatan Kabupaten Mojokerto. Jaksa Penuntut Umum juga menghadirkan dua orang saksi yaitu Joko Susanto, SH, dan Fitri Ade Novita yang membenarkan kejadian tersebut dan juga memberikan keterangan setelah kejadian tersebut telah terjadi perdamaian antara korban dan terdakwa yang dituangkan dalam surat perjanjian perdamaian tertanggal 7 Nopember $2011 .^{49}$

\section{Dakwaan dan Tuntutan Jaksa Penuntut}

Jaksa Penuntut Umum mendakwa terdakwa dengan dakwaan alternatif, dengan mempertimbangkan fakta-fakta yang terungkap di persidangan. Dalam hal ini Majelis Hakim hanya akan mempertimbangkan dakwaan yang kedua saja. Maka dari itu, untuk dipersalahkan melakukan tindak pidana sebagaimana pada dakwaan

\footnotetext{
${ }^{46}$ Putusan Pengadilan Negeri Mojokerto Nomor: 20/Pid.B/2012/PN.Mkt., 2.

${ }^{47} \mathrm{lbid}, 3$.

${ }^{48} \mathrm{lbid}, 4$.

${ }^{49} \mathrm{lbid}, 5$.
} 
kedua, perbuatan terdakwa harus memenuhi unsur-unsur dari pasal 80 ayat 91 UU. nomor 23 tahun 2002 tentang Perlindungan Anak, yaitu: ${ }^{50}$

"Setiap orang yang melakukan kekejaman, kekerasan atau ancaman kekerasan, atau penganiayaan terhadap anak, dipidana dengan pidana penjara paling lama 3 (tiga) tahun 6 (enam) bulan dan/atau denda paling banyak Rp 72.000.000,00 (tujuh puluh dua juta rupiah)"

Unsur yang pertama adalah setiap orang. Yang dimaksud dengan "Setiap orang"di sini adalah setiap subyek hukum sebagai pendukung hak dan kewajiban yang dapat mempertanggungjawabkan perbuatannya dan tidak digantungkan pada kwalitas/kedudukan tertentu. Berdasarkan pemeriksaan di persidangan, Philbert Titus Herdyanto Bin Pusoko Heru Santoso dapat dimintai pertanggung jawaban selaku terdakwa atas tindak pidana yang didakwakan kepadanya. Unsur yang kedua adalah melakukan kekejaman, kekerasan atau ancaman kekerasan, atau penganiayaan terhadap anak.

Jaksa Penuntut Umum mengajukan tuntutan pidana sebagaimana tersebut pada Surat Tuntutan No. Reg. Perk: PDM250/MKRTO/EP/2/12/2011 tertanggal 31 januari 2012 yang pada pokoknya menuntut:

a. Menyatakan terdakwa Philbert Titus Herdyanto Bin Pusoko Heru Santoso terbukti secara sah dan meyakinkan bersalah melakukan tindak pidana "Melakukan penganiayaan terhadap anak" sebagaimana diatur dan diancam pidana dalam pasal 80 ayat (1) UU. No. 23 tahun 2002 tentang Perlindungan Anak.

b. Menyatakan agar terdakwa Philbert Titus Herdyanto Bin Pusoko Heru Santoso dikembalikan kepada orang tuanya;

c. Menetapkan agar terdakwa dibebani membayar biaya perkara sebesar Rp. 5000, - (lima ribu rupiah). ${ }^{51}$

Selanjutnya atas tuntutan pidana dari Penuntut Umum tersebut, Terdakwa melalui Penasehat hukumnya mengajukan pembelaan secara lisan yang pada pokoknya Penasehat hukum Terdakwa sependapat dengan tuntutan Penuntut Umum dan tuntutan tersebut sudah tepat, dengan pertimbangan terdakwa masih anak di bawah umur dan sedang

\footnotetext{
${ }^{50}$ Ibid, 7.

51 lbid, 7.
} 
menempuh pendidikan (sebagai pelajar) di Sekolah Lanjutan Atas (SLTA).

\section{Pertimbangan Hakim dalam Putusan Nomor: 20/Pid.B/2012/Pn.Mkt}

Hakim Pengadilan Negeri Kelas I A Mojokerto dalam putusan yang bernomor 20/Pid.B/2012/Pn.Mkt memberikan beberapa pertimbangan, di antaranya sebagai berikut: ${ }^{52}$

a. Menimbang, bahwa berdasarkan hasil pemeriksaan sidang tidak terungkap adanya alasan pembenar/pemaaf sebagaimana ditentukan undang-undang dan perbuatan tersebut dapat dipertanggung jawabkan kepada terdakwa, oleh karena itu para terdakwa harus dinyatakan bersalah sehingga patut untuk dijatuhi hukuman;

b. Menimbang, bahwa mengenai pengenaan hukuman Hakim, sependapat dengan Penuntut Umum;

c. Menimbang, bahwa antara terdakwa dan orang tua terdakwa dengan saksi/korban Candika Nornanda Nova Risco Santa dan orang tuanya telah terjadi perdamaian di persidangan maupun dalam bentuk surat perjanjian perdamian tertanggal 17 Nopember 2011, diantara mereka sudah saling memaafkan dan tidak ada masalah lagi;

d. Menimbang, bahwa terdakwa masih anak-anak yang masih perlu bimbingan orang tua, maka pidana yang dijatuhkan sudah sepantasnya terdakwa tersebut dibimbing oleh orang tuanya;

e. Menimbang, bahwa karena terdakwa terbukti bersalah maka terdakwa juga dibebani untuk membayar biaya perkara;

f. Menimbang, bahwa sebelum Hakim menjatuhkan putusan, terlebih dahulu akan mempertimbangkan hal-hal yang memberatkan dan yang meringankan terdakwa:

Hal-hal yang memberatkan :-

Hal-hal yang meringankan :

i. Terdakwa menyesali perbuatannya;

ii. Terdakwa belum pernah dihukum;

${ }^{52} \mathrm{lbid}, 10-11$. 
iii. Terdakwa masih anak-anak dan masih sekolah di Sekolah Lanjutan Atas (SLTA);

iv. Antara terdakwa dengan korban dan keluarganya sudah saling memaafkan;

g. Mengingat pasal 80 ayat (1) UU. No. 23 tahun 2002 tentang Perlindungan Anak, Undang-undang No.3 tahun 1997 tentang Pengadilan Anak, UU. No. 8 tahun 1981 serta peraturan perundang-undangan lain yang bersangkutan;

Kemudian berdasarkan beberapa pertimbangan tersebut, hakim Pengadilan Negeri Mojokerto dalam putusan yang bernomor 20/Pid.B/2012/Pn.Mkt mengadili terdakwa dengan memberikan keputusan sebagai berikut:

a. Menyatakan Terdakwa Philbert Titus Herdyanto Bin Pusoko Heru Santoso telah terbukti secara sah dan meyakinkan bersalah melakukan tindak pidana "Melakukan penganiayaan terhadap anak"

b. Menyatakan agar terdakwa Philbert Titus Herdyanto Bin Pusoko Heru Santoso dikembalikan kepada orang tuanya;

c. Menyatakan barang bukti berupa 1 (satu ) buah Hp merk Nokia Tipe 2626 warna hitam tanpa kartu SIM dikembalikan kepada terdakwa;

d. Membebankan biaya perkara kepada terdakwa sebesar Rp 5.000, (lima ribu rupiah)..$^{53}$

Analisis Hukum Pidana Islam terhadap Pertimbangan Hakim Pengadilan Negeri Mojokerto dalam Kasus Penganiayaan yang Dilakukan oleh Anak dalam Putusan Nomor: 20/Pid.B/2012/PN.Mkt

Sebagaimana deskripsi kasus yang terdapat dalam putusan Pengadilan Negeri Mojokerto dengan Nomor: 20/Pid.B/2012/PN.Mkt bahwa terdakwa dalam kasus tersebut adalah Philbert Titus Herdyanto bin Pusoko Heru Santoso seorang anak berusia 15 (lima belas) tahun (lahir pada tanggal 24 April 1996) yang menurut UU. Nomor 11 tahun 2012 tentang Sistem Peradilan Pidana Anak termasuk dalam kategori anak.

\footnotetext{
${ }^{53}$ Putusan Pengadilan Negeri Mojokerto Nomor 20/Pid.B/2012/Pn.Mkt
} 
Terdakwa telah melakukan kekejaman, kekerasan atau ancaman kekerasan atau penganiayaan dengan memukulkan benda tumpul berupa HP terhadap seorang anak bernama Candrika Nornanda Nova Risco Santa yang mengakibatkan luka lecet dengan panjang kurang lebih setengah $\mathrm{cm}$ pada ujung pangkal alis kanan. Serta terdapat pendarahan di bawah kulit dengan ukuran lebih dua kali satu setengah $\mathrm{cm}$ pada bawah mata sebelah kanan. Juga terdapat pendarahan pada bola mata kanan.

Dengan perbuatan terdakwa sebagaimana disebutkan di atas, ia diancam pidana dengan pasal 80 ayat (1) UU. No. 23 tahun 2001 tentang Perlindungan Anak dan diancam juga dengan pasal 351 ayat (1) Kitab Undang-undang Hukum Pidana (KUHP). Jaksa Penuntut Umum mengajukan tuntutan pidana sebagaimana tersebut pada Surat Tuntutan No. Reg. Perk : PDM- 250/MKRTO/EP/2/12/2011 tertanggal 31 januari 2012 yang pada pokoknya menuntut :

1. Menyatakan terdakwa Philbert Titus Herdyanto Bin Pusoko Heru Santoso terbukti secara sah dan meyakinkan bersalah melakukan tindak pidana "Melakukan penganiayaan terhadap anak" sebagaimana diatur dan diancam pidana dalam pasal 80 ayat (1) UU. No. 23 tahun 2002 tentang Perlindungan Anak.

2. Menyatakan agar terdakwa Philbert Titus Herdyanto Bin Pusoko Heru Santoso dikembalikan kepada orang tuanya;

3. Menetapkan agar terdakwa dibebani membayar biaya perkara sebesar Rp. 5000, - (lima ribu rupiah).

Selanjutnya, Hakim Pengadilan Negeri Mojokerto mengadili dan memberikan putusan kepada Philbert Titus Herdyanto bin Pusoko Heru Santoso yang pada intinya sama persis seperti apa yang dituntutkan oleh Penuntut Umum dengan pertimbangan-pertimbangan sebagai berikut:

1. Berdasarkan hasil pemeriksaan sidang tidak terungkap adanya alasan pembenar/pemaaf sebagaimana ditentukan undang-undang dan perbuatan tersebut dapat dipertanggung jawabkan kepada terdakwa, oleh karena itu para terdakwa harus dinyatakan bersalah sehingga patut untuk dijatuhi hukuman;

2. Antara terdakwa dan orang tua terdakwa dengan korban Candika Nornanda Nova Risco Santa dan orang tuanya telah terjadi perdamaian di persidangan dalam bentuk Surat Perjanjian 
Perdamian tertanggal 17 Nopember 2011, diantara mereka sudah saling memaafkan dan tidak ada masalah lagi;

3. Terdakwa masih anak-anak yang masih perlu bimbingan orang tua, maka pidana yang dijatuhkan sudah sepantasnya terdakwa tersebut dibimbing oleh orang tuanya;

4. Dikarenakan terdakwa terbukti bersalah maka terdakwa juga dibebani untuk membayar biaya perkara;

5. Tidak ada hal yang memberatkan bagi terdakwa dan bahkan ada hal yang meringankan berupa:

a. Terdakwa menyesali perbuatannya,

b. Terdakwa belum pernah dihukum,

c. Terdakwa masih anak-anak dan masih sekolah di Sekolah Lanjutan Atas (SLTA);

d. Antara terdakwa dengan korban dan keluarganya sudah saling memaafkan.

Apabila ditinjau dari Undang-undang nomor 11 tahun 2012 tentang Sistem Peradilan Pidana Anak, pertimbangan hakim Pengadilan Negeri Mojokerto dalam mengadili dan memberikan putusan kepada terdakwa (Philbert Titus Herdyanto bin Pusoko Heru Santoso) ini sudah sesuai dengan apa yang diamanatkan oleh undang-undang dengan perincian sebagai berikut:

1. Terdakwa yang masih berusia 15 (lima belas) tahun masih tergolong anak, hal ini diatur dalam pasal 1 ayat (3) Undangundang nomor11 tahun 2012 tentang Sistem Peradilan Pidana Anak.

2. Antara terdakwa dengan korban dan keluarganya sudah saling memaafkan yang dibuktikan dengan surat perjanjian perdamian tertanggal 17 Nopember 2011. Menurut Undang-undang nomor 11 tahun 2012 tentang Sistem Peradilan Pidana Anak hal ini disebut dengan diversi yang diatur dalam pasal 5 sampai dengan Pasal 14, Pasal 29, Pasal 42 dan Pasal 52 ayat (2) sampai dengan ayat (6). Dalam kasus ini diversi wajib dilaksanakan karena terdakwa bukan termasuk residivis (terdakwa belum pernah dihukum sebelumnya).

3. Kejahatan yang dilakukan terdakwa termasuk tindak pidana ringan. Yang mana, ringannya perbuatan, keadaan pribadi Anak, atau 
keadaan pada waktu dilakukan perbuatan atau yang terjadi kemudian dapat dijadikan dasar pertimbangan hakim untuk tidak menjatuhkan pidana atau mengenakan tindakan dengan mempertimbangkan segi keadilan dan kemanusiaan. Hal ini tertulis dalam pasal 70 Undang-undang nomor11 tahun 2012 tentang Sistem Peradilan Pidana Anak.

4. Maka, hukuman yang dijatuhkan kepada terdakwa adalah hukuman tindakan berupa pengembalian kepada orang tua/wali. Ketentuan ini tertulis dalam pasal 82 Undang-undang nomor 11 tahun 2012 tentang Sistem Peradilan Pidana Anak.

Adapun menurut ketentuan hukum pidana Islam, terdakwa (Philbert Titus Herdyanto bin Pusoko Heru Santoso) yang merupakan seorang anak yang sudah berusia 15 (lima belas) dalam permasalahan ini sudah memenuhi ketentuan baligh. Ia sudah mukallaf dan dapat dijatuhi hukuman karena sudah dianggap mampu untuk mempertanggungjawabkan tindak kejahatan yang telah dilakukannya.

Dalam hukum pidana Islam, tindak pidana perlukaan yang dilakukan khusus pada bagian muka dan kepala disebut dengan al-syajjâj. Apabila dilakukan dengan sengaja, maka ketentuan hukuman pokok (hukuman asli) yang harus diterapkan kepada pelaku al-syajjâj adalah hukuman qishâsh. Kecuali jika korban memaafkan kejahatannya tersebut. ${ }^{54}$ Adapun hukuman pengganti dalam kasus penganiayaan ini, menurut ijma' (kesepakatan) ahli fikih adalah diyat. ${ }^{55}$

Sedangkan tindak pidana penganiayaan yang dilakukan oleh Philbert Titus Herdyanto bin Pusoko Heru Santoso terhadap Candrika Nornanda Nova Risco Santa tidak termasuk dalam kategori al-syajjâj, karena pemukulan yang dilakukan tidak mengakibatkan luka, melainkan hanya memar, muka merah, terasa sakit, dan sedikit luka lecet dengan panjang kurang lebih setengah $\mathrm{cm}$ pada ujung pangkal alis kanan. Serta terdapat pendarahan di bawah kulit dengan ukuran lebih dua kali satu setengah $\mathrm{cm}$ pada bawah mata sebelah kanan (memar). Maka dalam kasus ini tidak berlaku hukuman qishâsh, karena menurut ketentuan hukum pidana Islam, tindakan penempelengan, pemukulan dengan cambuk dan tongkat semuanya tidak dikenakan hukuman qishâsh apabila tidak

\footnotetext{
${ }^{54}$ Zainuddin Ali, Hukum Islam Pengantar Ilmu Hukum di Indonesia, 128.

${ }^{55}$ A. Rahman Ritonga et al, Ensiklopedi Hukum Islam, 1387.
} 
meninggalkan bekas. Hukumannya adalah ganti rugi yang tidak tertentu atau hukûmah, yaitu ganti rugi yang ketentuannya diserahkan kepada kebijaksanaan dan ijtihad hakim dan ini hampir mirip dengan ta'zîr. ${ }^{56}$

\section{Simpulan}

Menurut Undang-undang nomor 11 tahun 2012 tentang Sistem Peradilan Pidana Anak batas usia dewasa anak adalah 18 tahun. Dalam undang-undang tersebut dijelaskan bahwa yang dimaksud dengan anak adalah anak yang telah berumur 12 (dua belas) tahun tapi belum berumur 18 (delapan belas) tahun. Adapun ketentuan pidana bagi anak dalam Undang-undang nomor 11 tahun 2012 dibagi menjadi dua yaitu:

a. Anak yang berusia antara 12 (dua belas) tahun sampai usia 14 (empat belas) tahun hanya dikenai hukuman tindakan.

b. Anak yang berusia antara 14 (empat belas) tahun sampai 18 (delapan belas) tahun dapat dijatuhi tindakan dan sanksi pidana.

Sedangkan menurut hukum pidana Islam, batas usia dewasa anak adalah baligh. Salah satu tanda usia baligh bagi seorang anak adalah ihtilâm (mimpi bersetubuh ditandai dengan keluarnya air mani) atau telah sampai usia 15 (lima belas) tahun bagi anak laki-laki dan sudah haid(keluarnya darah sebab menstruasi) bagi anak perempuan. Apabila usia anak belum mencapai baligh (masih di bawah umur), maka tidak bisa dijatuhi hukuman atas kejahatan yang dilakukan mengingat kondisi si pelaku itu sendiri yang biasanya disebut dengan unsur pemaaf.

Hakim Pengadilan Negeri Mojokerto menjatuhkan hukuman kepada Philbert Titus Herdyanto bin Pusoko Heru Santoso berupa hukuman tindakan yaitu mengembalikannya kepada orang tua/walinya dengan pertimabangan sebagai berikut:

a. Masih tergolong anak di bawah umur (menurut hukum positif),

b. Kejahatan berupa penganiayaan yang dilakukan adalah kejahatan ringan,

c. Korban sudah memaafkan (dibuktikan dengan surat perjanjian perdamian tertanggal 17 Nopember 2011).

Adapun menurut hukum pidana Islam, terdakwa adalah seorang anak yang sudah berusia 15 (lima belas) dalam permasalahan ini sudah memenuhi ketentuan baligh. Ia sudah mukallaf dan dapat dijatuhi sanksi

\footnotetext{
${ }^{56}$ Ahmad Wardi Muslich, Hukum Pidana Islam, 218.
} 
pidana layaknya orang dewasa karena ia sudah dianggap mampu untuk mempertanggungjawabkan tindak kejahatan yang telah dilakukannya. Namun, tindak penganiayaan yang dilakukan oleh terdakwa tidak termasuk dalam kategori al-syajjâj yang dalam hukum pidana Islam berarti tindak pidana pelukaan yang dilakukan khusus pada bagian muka dan kepala. Karena pemukulan yang dilakukan itu tidak sampai mengakibatkan luka berat, maka dalam kasus ini tidak berlaku hukuman qishâsh. Hukumannya adalah ganti rugi yang tidak tertentu atau hukûmah, yaitu ganti rugi yang ketentuannya diserahkan kepada kebijaksanaan dan ijtihad hakim dan ini hampir mirip dengan ta'zîr. Maka, kesimpulannya adalah keputusan yang dijatuhkan oleh hakim Pengadilan Negeri Mojokerto kepada Philbert Titus Herdyanto bin Pusoko Heru Santoso berdasarkan pertimbangan-pertimbangan yang telah disebutkan tidaklah bertentangan dengan ketentuan hukum yang terkandung dalam hukum pidana Islam.

\section{Daftar Rujukan}

A. Djazuli. Hukum Pidana Islam. Bandung: Pustaka Setia, 2000.

'Audah, Abd al-Qadir. al-Tasyrî̀ al-Jinẩiy al-Islâmiy. Beirut: Muassasah al-Risalah, 1992.

Doi, Abdurrahman I. Tindak Pidana dalam Syari'at Islam. Jakarta: Rineka Cipta, 1992.

Dawud, Abu. Sunan Abi Dawud. Beirut: Dar al-Fikr. 1994.

Bahansi, Ahmad Fathi. al-'Uqûbah fî al-Fiqh al-Islâmiy. Kairo: Dar alSyuruq, 1989.

Muslich, Ahmad Wardi. Hukum Pidana Islam. Jakarta: Sinar Grafika, 2005.

. Pengantar dan Asas Hukum Pidana Islam. Jakarta: Sinar Grafika, 2004.

Munawwir, Ahmad Warson. Al-Munawwir. Surabaya: Pustaka Progresif, 1997.

Yafie, Ali. et al. Ensiklopedia Hukum Pidana Islam. Jilid 4. Bogor: PT Kharisma Ilmu.

Syarifuddin, Amir. Hukum Perkawinan Islam di Indonesia antara Fiqh Munakahat dan UU. Perkawinan. Jakarta: Kencana Prenada media, 2009. 
Hidayat, Bunadi. Pemidanaan Anak Di Bawah Umur. Bandung: PT Alumni, 2014.

Prinst, Darwan. Hukum Anak di Indonesia. Bandung: PT. Citra Aditya Bakti, 1997.

Rosyada, Dede. Hukum Islam dan Pranata Sosial. Jakarta: Lembaga Studi Islam dan Kemasyarakatan, 1992.

Sumaryono, E. Kejahatan Anak: Suatu Tinjauan dari Psikologi dan Hukum. Yogyakarta: Liberty, 1985.

Manan, Bagir. Hukum Positif Indonesia. Bandung: CV Mandar Maju, 2005.

Suhendi, Hendi. Fiqh Muamalah. Jakarat: Raja Grafindo Persada, 2008.

Rusyd, Ibnu. Bidâyah al-Mujtahid Analisa Fikih para Mujtahid. Jakarta: Pustaka Amani, 2007.

Koesparmono, Irsan. HukumPerlindunganAnak. Jakarta: UPN, 2006.

Mubarok, Jaih. Enceng Arif Faizal. Asas-Asas Hukum Pidana Islam. Jakarta: Anggota IKAPI, 2004.

Quraisy, 2004.

Praja, Juhaya S. Filsafat Hukum Islam. Bandung: LPPM-Universitas Islam.

Irfan, M. Nurul. Masyrofah. Fiqh Jinâyah. Jakarta: Amzah, 2013.

Ali, Mohammad Daud. Hukum Islam. Jakarta: PT. RajaGrafindo Persada, 2007.

Abu Syuhbah, Muhammad bin. al-Hudûd fî al-Islâm wa Muqâranatuhu bi al-Qawânîn al-Wadh'iyah. Kairo: al-Hay'ah al-'Ammah li Syu'ûn al-Mathâbi' al-Amîriyyah, 1974.

Qal'ahji, Muhammad Rawwas. Ensiklopedi Fiqh Umar bin Khattab. Jakarta: PT Raja Grafindo Persada, 1999.

Thohir, Muhammad. Seminar Kesehatan Anak. Surabaya: Rumah Sakit Islam Surabaya, 1993.

Poerwadarminta. Kamus Umum Bahasa Indonesia. Jakarta: Balai Pustaka, 1976.

Kamus Bahasa Indonesia. Jakarta: Balai Pustaka, 1989.

Syihab, Quraisy. Mempersiapkan Anak Sholeh. Jakarta: Raja Grafindo Persada, 1996. 
Ritonga, Rahman. et al. Ensiklopedi Hukum Islam. Jakarta: PT. Ichtiar Baru van Hoeve, 2006.

Hakim, Rahmat. Hukum Pidana Islam. Bandung, CV. Pustaka Setia, 2000.

Widi, Restu Kartiko. Asas Metodelogi Penelitian. Yogyakarta: Graha Ilmu, 2010.

Sabiq, Sayyid. Fiqh Sunnah. Beirut: Dar Al-Fikr, 1983.

Sumarsono, Sonny. Metode Riset Sumber Daya Manusia. Yogyakarta: Graha Ilmu, 2004.

Sudarsono. Kamus Hukum. Jakarta: PT. Rineka Cipta, 1992.

Kenakalan Remaja. Jakarta : Rineka Cipta, 1991.

Usman, Suparman. Hukum Islam. Jakarta: Gaya Media Pratama, 2001.

ash-Shiddieqy, Teungku Muhammad Hasbi. Tafsîr al-Qur'ân al-Majîd an-Nûr, Jilid 4. Semarang: PT. Pustaka Rizki Putra, 2000.

Al-Zuhaili, Wahbah. Al-Fiqh al-Islâmiy wa Adillatuh. Beirut: Dar al-Fikr, 1997.

Ghafur, Waryono Abdul. Tafsir Sosial Mendialogkan Teks dengan Konteks. Yogyakarta: elSAQ Press, 2005.

Ali, Zainuddin. Hukum Islam Pengantar Ilmu Hukum di Indonesia. Jakarta: Sinar Grafika, 2006.

Kementrian Agama. al-Qur'an dan Tafsirnya. Jakarta: Widya Cahaya, 2011.

Kitab Undang-Undang Hukum Perdata.

Kitab Undang-Undang Hukum Pidana.

Putusan Pengadilan Negeri Kelas I A Mojokerto Nomor 20/Pid.B/2012/Pn.Mkt

UU. No. 1 Tahun 1974 tentang Perkawinan.

UU. No. 23 Tahun 2002 tentang Perlindungan Anak.

UU. No. 3 Tahun 1997 tentang Pengadilan Anak.

UU. Nomor 11 Tahun 2012 tentang Sistem Peradilan Anak. 